\title{
Sustainability of the Funded Ratio and Asset Allocation Choice of State Public Pension Plans
}

\author{
Amod Choudhary (Corresponding author) \\ City University of New York, Lehman College \\ Department of Economics and Business \\ Carman Hall 377, 250 Bedford Park Blvd. West \\ Bronx, NY 10458, USA
}

Tel: 1-718-960-8297Ｅ-mail: amod.choudhary@lehman.cuny.edu

\author{
Nikolaos Papanikolaou \\ City University of New York, Lehman College \\ Department of Economics and Business \\ Carman Hall 377, 250 Bedford Park Blvd. West \\ Bronx, NY 10458, USA
}

Received: February 17, 2019

Accepted: March 4, 2019 Published: March 4, 2019

doi:10.5296/ijafr.v9i1.14358

URL: https://doi.org/10.5296/ijafr.v9i1.14358

\begin{abstract}
The paper examines State Public Pension Plans in the United States and the sustainability of their funded ratios. The authors apply a panel logit with random effects regression model of asset allocation choice and average returns during fiscal years 2001 to 2015 . There are three key factors which adequately fund State Public Pension Plans: (i) current member contributions, (ii) members' employer contributions, and (iii) investment returns on those contributions. Returns on those contributions depend heavily on allocation choice of those funds in traditional and alternative investments. Alternatives are generally assumed to provide higher average returns with higher risk. This paper shows that in the long-term, investment in traditional assets such as bonds, equities and short-term cash have a higher likelihood of funding State Public Pension Plan's payment obligations to beneficiaries.
\end{abstract}

Keywords: State public pension plans, Funding ratio, Alternatives, Panel logit/random effects model 


\section{Introduction}

The level of pension funding has been an ongoing concern for politicians and public-sector retirees. Mainly, the amount needed to pay out in benefits to retirees who have state public pensions is considerably less than the amount available to pay the promised benefits. This gap in benefits paid to retirees and available funds to make those payments is known as the Funded Ratio. More precisely, a Funded Ratio is the ratio of pension assets over pension liabilities (Mohan \& Zhang, 2014). A fund is underfunded when the assets are not sufficient to cover the projected liabilities (Listokin et al., 2015). From 2001 to 2009 public pension plans lost value and had decreasing funded ratios (Wang \& Peng, 2016). This gap is due to years of low employer contributions, optimistic investment return assumptions, generous promise of benefits, two recessions (early 2000s and 2008), and higher number of baby boomers retiring (Gillers, 2017). Gillers (2017) also reported that the collective short fall is approximately anywhere from $\$ 1.6$ to $\$ 4$ trillion. A public pension plan's funds (or assets) are made-up of contributions of the employee, employer and the returns on these contributions through investments in various financial instruments. Generally, asset allocation of State Public Pension Plans (SPPP) is invested in equities, bonds, cash, and alternatives (Note 1). Alternative assets are investments in high-risk high-reward instruments such as hedge funds, commodities, private equity, real estate and commodities (Aubry et al., 2017). Returns on these investments are crucial for a pensions plan's solvency, since employee and employer contributions are very difficult to increase due to political pressures. Wang \& Peng (2016, p. 88) conclude that "investment return has a significant impact on funded ratios." Prior to 2008 financial crisis, SPPPs invested mostly in traditional assets such as cash, bonds, and equities. However, after the 2008 financial crisis, pension plans have moved more of their assets in alternatives. Aubry et al. (2017) note that allocation of assets in alternatives changed from $9 \%$ in 2005 to $24 \%$ in 2015. Stated reasons for investing in alternatives are potential higher returns, diversification and hedging against investment risks in the portfolio (Listokin et al., 2015; Aubry et al., 2017). Unfortunately, this change in asset allocation has not necessarily resulted in higher investment returns. Aubry et al. (2017) find in their analysis of data from Public Plans Database (Note 2) (which covers nearly $95 \%$ of pension assets) that there was negative relationship between alternatives and returns of investment portfolios. Generally, pensions have the option to allocate their investments in any combination of equities, bonds, alternatives, cash, real estate and other (Note 3) (Public Plans Database, 2017) (Note 4). Since we are unable to determine the funding strategy (or in other words the desired returns) of various pension plans, we select a standard/benchmark against which to compare the portfolio returns. We think that using the funded ratio is the appropriate benchmark. Pension funds with ratios (of accumulated assets to the pension benefit obligation) less than 80\% (0.80) are considered to be underfunded (Listokin et al., 2015; Elder \& Wagner, 2016).

The remainder of this paper is divided into four sections: Section 2--Literature Review, Section 3--Data \& Methodology, Section 4--Empirical Results, and Section 5--Conclusion. 


\section{Literature Review}

Movement towards increasing investment in alternatives is undoubtedly due to poor returns on stocks during the 2008-2009 financial crisis. Mohan \& Zhang (2014) argue that public pension funds undertake more risk if they are underfunded and have lower investment returns in the previous years, and States that are facing increasing fiscal restraints lead to pension funds allocating more assets to equity with higher betas (Note 5). Similarly, Pennacchi \& Rastad (2011) show that pension funds choose higher liability risk after a period of poor investment performance and also choose riskier portfolios when they select higher discount (expected investment returns) rates. Additionally, government accounting standards strongly affect pension fund risk, as higher return assumptions are associated with higher equity allocation and portfolio beta. Lucas \& Zeldes (2009) show that there is a trade-off between the higher average return on equities which lowers average tax [receipts] and the greater risk of equities which increases expected tax distortions. They also conclude that there is a positive correlation between stock returns and pension liabilities over longer horizons (reduce the need to raise revenues through distortionary taxes); then holding some equities can serve as a partial hedge against liabilities, providing an additional reason for holding equities. Aubry et al. (2017) focus on shift in alternative investment allocation from $9 \%$ to $24 \%$ (from 2005 to 2015) and the impact of this shift on investment returns and volatility. They find that alternatives result in lower investment returns primarily due to poor performance of hedge funds with no reductions in volatility. They clarify that hedge funds do reduce volatility, although that reduction in volatility is canceled by the increased volatility associated with real estate and commodities. Hoevenaars et al. (2008) find that alternative assets add value for long-term investors. They find that hedge funds have good inflation hedging qualities in the long-term, but a high exposure to stocks and bonds. Wang \& Peng (2016) examine 84 large public pensions between 2001-2009; and recommend that pension plans seeking to improve their funded ratios need to revise their investment strategies, pay a higher percentage of their required contribution, require employees to pay more toward their pension benefits, and limit the use of automatic or consumer price index-linked cost-of-living adjustments (COLA). More importantly, they find that investment return has a significant impact on funded ratios. Listokin et al. (2015) discuss the prevalence of shift towards more investments in alternatives. Based on analysis of four pension plans they find that there is a lack of consistent practice or governance structures for investments in hedge funds and private equity. Aglietta et al. (2012) find that active management of pension funds plays a predominant role in explaining returns to individual asset classes regardless of whether it is traditional (equities, fixed income, and cash) or alternative (real assets, private equity, hedge funds, and tactical asset allocation) assets. Stalebrink (2014) finds that adoption of investment return assumption associated with public sector defined benefit pension plans may be partly explained by political opportunism. Adopted investment return assumptions are partly determined by investment boards' affiliation with the political process. Dobra \& Lubich (2013) focus on board compositions and asset allocation in public pension plans. Their paper notes that pension board composition in addition to influencing asset allocation, also affects portfolio risk (increase in size increases risk-beta). They qualify that asset allocation is one of the main determinants of investments returns in addition to governance of public pensions. While Kanuri \& McLeod 
(2014) find that performance of AMF (alternative mutual funds) don't create value for investors and performed worse during the recession of 2008. AMF funds are similar to hedge funds and marketed to individual investors who prefer non-correlation returns (higher returns in all market conditions) and diversification benefits. Typically, AMF securities are underpriced and short-overpriced securities use leverage, derivatives, options and swaps to seek higher returns. AMFs have more flexibility compared to mutual finds however more constraints than hedge funds. An analysis of U.K. pension funds by Groot \& Swinkels (2008) show that the allocation in alternatives from $15-30 \%$ results in expected returns of $2-3 \%$. Kraussel et al. (2017) find that investments in alternative assets have increased considerably in last two decades and recommend further research undertaken to show the long-term benefits of alternative investments.

We add to the literature by examining fifteen years of SPPP data to determine whether investments in alternatives increase the funding ratio of SPPP in the United States. Jackwerth \& Slavutskaya (2016) conclude that investments in hedge funds are more beneficial than investments in other alternative assets such as real estate, commodities, foreign equity, mutual funds and other. They find that during recessions hedge funds outperform other alternative assets such commodities, real estate, foreign equities and inverse ETFs. In contrast, our study is distinguished from Jackwerth \& Slavutskaya (2016), because we analyze U.S. defined pension plans, collectively examine the performance of all alternatives over a fifteen-year period, apply a panel logit regression model to determine asset allocation choice, and the likelihood of a sustainable funded ratio. Blake et al. (2017) analyze 25 years of pension fund data in UK, and conclude that asset allocation tends to herd (follow other similar funds) in the short-term and in sub groups such as public/private funds and size. They also state that pension funds rebalance their portfolios mechanically (independent of expected returns) in the short-term and follow a strategic asset allocation based on maturing liabilities in long-term. Therefore, the asset allocation observed in our study of SPPP follow a similar pattern and is likely to persist with similar size pension plans.

\section{Data \& Methodology}

The data analysed in this paper is obtained from the Public Plans Data database (Note 6) which is developed and maintained through a collaboration of the Center for Retirement Research at Boston College, the Center for State and Local Government Excellence, and the National Association of State Retirement Administrators. As stated in the Public Plans Data overview statement (Note 7) on public sector retirement systems, roughly 6,000 public sector retirement systems exist in the U.S. Some of the 299 state-administered plans and 5,977 locally-administered plans date back to the $19^{\text {th }}$ century and each has evolved independently. Collectively, these plans have $\$ 3.74$ trillion in assets, 14.7 million active (working) members, 0.3 million retirees and $\$ 282.899$ billion in benefit distributions annually (Note 8 ). The data analysed consists of 160 pension plans from 2001 to 2015 (Note 9).

The mean funded ratio (barometer for sustainability of SPPP) has declined from 99.7 (2001) to 72.9 (2015), a decrease of $37 \%$ over a fifteen-year period. While the median funded ratio declined from 99.4 (2001) to 73.6 (2015), a decrease of 26\% (see table 1). The subsequent 


\section{$\triangle$ Macrothink}

International Journal of Accounting and Financial Reporting

ISSN 2162-3082

2019, Vol. 9, No. 1

decline in the funded ratio coincided with an increase in pension plans portfolio which comprise of alternative assets. In 2001, pension plans average asset allocation in alternatives is $2.8 \%$, which increased to $17.1 \%$ in 2015 . The pattern of allocating a greater portion of the pension plans portfolio in alternative assets to compensate for losses on investments during and after the financial crisis of 2008-2009 is evident for years 2008 to 2015. Consequently, an increase in alternative asset allocation means fewer funds are allocated into traditional assets such as bonds and equities. In 2001, asset allocation in U.S. bonds were $12.9 \%$ and in U.S. equities 34.8\%; while in 2015; asset allocation in U.S. bonds were 5.6\% and U.S. equities were $12.7 \%$--a decrease of $15 \%$ and $64 \%$ respectively.

The asset allocation decisions by pension funds' money managers to re-direct investment away from traditional assets such as bonds and equities to alternatives has not led to an increase in the funded ratio (see Table 1). In 2001, investment in alternative assets was $2.8 \%$ with a funded ratio of $99.7 \%$; while in 2015 , investment in alternative assets increased to $17.1 \%$ with a funded ratio of $72.9 \%$. This is an increase in asset allocation into alternative assets from 2001 to 2015 of $511 \%$, with a subsequent decline in the funded ratio of $27 \%$. The strategy of investing in high-risk assets such as alternatives to provide higher returns has not solved the problem of an under-funded ratio. Our analysis shows (see Table 2) that diverting funds from traditional assets such as bonds and equities into alternatives decreases the likelihood of maintaining a funded ratio at or above a sustainable level or benchmark of $80 \%$. From 2001 to 2007, pre- financial crisis, SPPP invested at the lower bound (2.8\%) and upper bound $(6.3 \%)$ in alternative assets. While in the post-financial crisis there was a substantial increase of asset allocation into alternatives in both the lower bound (9\%) and upper bound (17.9\%). Asset allocation and investment pre-financial crisis comprised of less risk and moderate returns, whereas post-financial crisis introduced greater levels of uncertainty due to investments in short-term higher-risk and higher-return assets. The end result is SPPP are unable to cover their long-term payment obligations to future retirees.

Table 1. State public pension plans asset allocation (\%) and the funded ratio by year

\begin{tabular}{|c|c|c|c|c|c|c|c|c|c|c|c|c|c|c|c|}
\hline Asset & 2001 & 2002 & 2003 & 2004 & 2005 & 2006 & 2007 & 2008 & 2009 & 2010 & 2011 & 2012 & 2013 & 2014 & 2015 \\
\hline Alternatives & 2.8 & 2.9 & 3.1 & 3.3 & 3.7 & 5.1 & 6.3 & 9.0 & 10.5 & 11.7 & 13.2 & 15.4 & 16.1 & 16.4 & 17.1 \\
\hline Cash & 2.7 & 2.2 & 2.9 & 2.6 & 2.0 & 2.1 & 2.4 & 2.1 & 2.6 & 2.5 & 2.4 & 1.9 & 2.0 & 2.2 & 2.2 \\
\hline Int. Bonds & 1.2 & 1.3 & 1.0 & 0.9 & 1.1 & 0.9 & 0.8 & 1.1 & 1.0 & 0.9 & 0.9 & 0.9 & 1.0 & 1.2 & 0.9 \\
\hline Int. Equities & 10.9 & 11.6 & 12.0 & 13.4 & 14.5 & 15.1 & 16.5 & 15.5 & 15.8 & 15.9 & 16.7 & 16.2 & 16.5 & 17.1 & 16.5 \\
\hline Other & 1.2 & 1.3 & 1.3 & 1.0 & 0.9 & 0.4 & 0.5 & 0.8 & 0.9 & 1.2 & 1.5 & 1.4 & 1.8 & 1.9 & 1.7 \\
\hline Real Estate & 3.6 & 4.1 & 3.8 & 3.9 & 4.1 & 4.9 & 5.1 & 6.2 & 5.5 & 5.3 & 5.7 & 6.1 & 6.0 & 6.1 & 6.2 \\
\hline U.S. Bonds & 12.9 & 13.0 & 10.9 & 10.0 & 9.3 & 8.4 & 8.2 & 8.8 & 8.7 & 8.2 & 6.8 & 6.2 & 6.5 & 6.1 & 5.6 \\
\hline U.S. Equities & 34.8 & 34.8 & 36.1 & 37.3 & 37.3 & 36.1 & 35.3 & 30.6 & 26.4 & 25.5 & 25.4 & 25.1 & 24.7 & 723.6 & 12.7 \\
\hline Mean Funded Ratio & 99.7 & 93.0 & 87.9 & 85.2 & 83.3 & 83.4 & 84.7 & 82.4 & 76.9 & 74.7 & 73.5 & 71.1 & 72.6 & 672.3 & 72.9 \\
\hline Median Funded Ratio & 99.4 & 93.4 & 89.2 & 85.5 & 84.8 & 84.3 & 86.1 & 82.7 & 77.2 & 74.5 & 73.2 & 71.2 & 72.6 & $6 \quad 73.3$ & 73.6 \\
\hline
\end{tabular}

Note: The table shows asset allocation by year.

In Table 2, we calculate long-term average returns for years 10 and 15 for SPPP based on asset allocation in alternatives as well as pension plans which excluded alternatives from the portfolio entirely. Our findings show that during the economic recession of 2008-2009, pension plans which excluded alternatives from their portfolios had smaller losses in contrast to pension plans that included alternatives as an investment strategy. In non-recession years 


\section{Mll Macrothink}

International Journal of Accounting and Financial Reporting

ISSN 2162-3082

2019, Vol. 9, No. 1

the findings are inconclusive, and results illustrate that portfolios with alternatives do not necessarily lead to higher average investment returns (in contrast with portfolios excluding alternatives).

Table 2. Long-Term average returns $(\%)$

\begin{tabular}{|c|c|c|c|c|c|c|c|c|c|c|c|c|c|c|c|}
\hline Average Returns & 2001 & 2002 & 2003 & 2004 & 2005 & 2006 & 2007 & 2008 & 2009 & 2010 & 2011 & 2012 & 2013 & 2014 & 2015 \\
\hline $10 \mathrm{yr}$ & & & & & & & & & & & & & & & \\
\hline Inv. Alt. $=0$ & 10.0 & 8.1 & 7.4 & 9.6 & 8.7 & 8.2 & 7.9 & 5.5 & 3.5 & 3.7 & 5.2 & 6.6 & 7.2 & 7.0 & 6.1 \\
\hline Inv. Alt $>0$ & 10.9 & 9.1 & 8.6 & 9.8 & 9.3 & 8.9 & 8.4 & 5.6 & 3.1 & 3.6 & 5.7 & 6.8 & 7.3 & 7.2 & 6.5 \\
\hline $15 \mathrm{yr}$ & & & & & & & & & & & & & & & \\
\hline Inv. Alt. $=0$ & -3.0 & -3.7 & -.59 & 2.6 & 3.7 & 4.5 & 5.5 & 3.7 & 2.7 & 3.3 & 4.1 & 4.5 & 5.1 & 5.9 & 5.3 \\
\hline Inv. Alt. $>0$ & -5.4 & -5.4 & -1.3 & 2.4 & 4.0 & 5.1 & 6.9 & 4.5 & 2.5 & 3.5 & 4.6 & 4.5 & 5.1 & 5.7 & 5.7 \\
\hline
\end{tabular}

Note: The table shows long-term average returns 10 and 15 years for SPPP that excluded alternatives from their portfolio ( $\mathrm{Alt}=0$ ) and pension plans which included alternatives $\mathrm{Alt}>0$ ) from 2001 to 2015. Average returns for 10 years in 2001 are calculated from 1991 to 2001 and in the case of 2002 from 1992 to 2002, respectively. Average returns for 15 years in 2001 are calculated from 1986 to 2001, and in the case of 2002from 1987 to 2002, respectively. This process is repeated for the subsequent years 2003 to 2015, respectively.

In Table 3, we derive average asset allocation in conjunction with the funded ratio threshold below, equal to, and above the $80 \%$ benchmark. Column 3 below shows that lower levels of investment in international bonds, international equities, alternatives, and real estate over the period of 2001 to 2015 are associated with a funded ratio at or above the benchmark of $80 \%$, relative to higher allocation in those asset classes as shown in column 2.

Table 3. Asset allocation and funded ratio

\begin{tabular}{|c|c|c|c|}
\hline & $\begin{array}{c}1] \\
\text { Funded Ratio } \\
(80 \%)\end{array}$ & $\begin{array}{c}{[2]} \\
\text { Funded Ratio } \\
(<80 \%)\end{array}$ & $\begin{array}{c}{[3]} \\
\text { Funded Ratio } \\
(>80 \%)\end{array}$ \\
\hline U.S. Bonds & 8.7 & 8.7 & 8.6 \\
\hline Int. Bonds & 1.1 & 1.3 & 0.76 \\
\hline U.S. Equities & 30.3 & 29.9 & 30.7 \\
\hline Int. Equities & 14.9 & 16.4 & 13.6 \\
\hline Alternatives & 9.1 & 11.3 & 7.1 \\
\hline Short-term cash & 2.3 & 2.2 & 2.5 \\
\hline Other Assets & 1.2 & 1.1 & 1.3 \\
\hline Real Estate & 5.1 & 5.3 & 5.0 \\
\hline
\end{tabular}

Note: This table shows the authors' calculations of three different thresholds of the funded ratio benchmark of less than, equal to and greater than eighty-percent corresponding to subsequent choice portfolio asset allocation classes from 2001 to 2015.

SPPP average returns is a key driver underlying the funded ratio. In this paper, average returns are based on average asset allocation (see Table 1) in alternatives at $9.1 \%$, short-term cash at $2.3 \%$, international bonds at $1 \%$, U.S. bonds at $8.6 \%$, international equities at $14.9 \%$, U.S. equities at $29.7 \%$, real estate at $5.1 \%$ and other at $1.2 \%$.

The SPPP asset allocation for years 2001 to 2015 follow a random sampling process from an underlying data generating process (DGP). We used a cluster-robust version of Hausman's specification test (Note 10) due to the nature of clustering among state pension plans over the time horizon of 2001 to 2015 to determine appropriate logit panel regression model. The Hausman test results (Note 11) confirm that a logit panel regression model with random 


\section{Macrothink}

International Journal of Accounting and Financial Reporting

ISSN 2162-3082

2019, Vol. 9, No. 1

effects correcting for clustering by state pension plans will produce consistent estimates of coefficients $\hat{\beta}$ and standard estimator for the variance $\hat{V}[\hat{\beta}]$ (Cameron \& Miller, 2015). The composite error term for the random effects model is defined as $\varepsilon_{i t}=v_{i}+u_{i t}$. The general binary panel regression model with random effects in our paper is defined as:

$$
\operatorname{Pr}\left(y_{i t} \neq 0 \mid x_{i t}\right)=P\left(x_{i t} \beta+v_{i}+\varepsilon_{i t}\right)
$$

for $\mathrm{i}=1, \ldots, \mathrm{n}$, panels and $\mathrm{t}=1, \ldots, \mathrm{n}$, annual time periods. Where $v_{i}$ is individual specific effects that are independently and identically distributed (iid) and assumed to be normally distributed, $N\left(0, \sigma_{v}^{2}\right)$. The logistic function is $P(z)=\{1+\exp (-z)\}^{-1}$ and the variance components model of the panel level, $\ln \left(\sigma_{v}^{2}\right)$, standard deviation $\sigma_{v}$, and the inter-class correlation of the error term which explains the proportion of the overall variance contributed by the panel level variance, $\rho=\frac{\sigma_{v}^{2}}{\sigma_{v}^{2}+\sigma_{\varepsilon}^{2}}$, respectively, underlying the panel logit random effects model, $y_{i t} \neq 0 \Leftrightarrow x_{i t} \beta+v_{i}+\varepsilon_{i t}>0$. The idiosyncratic error, $\varepsilon_{i t}$ is iid and distributed as a logistic distribution $\operatorname{Pr}\left(\varepsilon_{i t} \leq \alpha\right)=\frac{1}{1+\exp (-\alpha)}$, symmetric about mean zero and a variance $\sigma_{\varepsilon}^{2}=\frac{\pi^{2}}{3}$ and independent of $v_{i}$. Therefore, we obtain $\operatorname{Pr}\left(y_{i t}=1\right)=\operatorname{Pr}\left(y_{i t}>0\right)=\operatorname{Pr}\left(\varepsilon_{i t} \leq x_{i t}^{\prime} \beta\right)=\frac{1}{1+\exp \left(-x_{i t}^{\prime} \beta\right)}$.

Furthermore, we assume a normal distribution, $N\left(0, \sigma_{v}^{2}\right)$, for the random effects $v_{i}$, obtaining the binary probability model of SPPP defined as:

$$
\operatorname{Pr}\left(y_{i 1}, \ldots, y_{i n_{i}}\right)=\int_{-\infty}^{\infty} \frac{\mathrm{e}^{\frac{-v_{i}^{2}}{2 \sigma_{v}^{2}}}}{\sqrt{2 \pi \sigma_{v}}}\left\{\prod_{t=1}^{n_{i}} F\left(y_{i t,}, x_{i t} \beta+v_{i}\right\} d v_{i}\right.
$$

Where,

$$
F(y, z)=\left\{\frac{\frac{1}{1+\exp (-z)} \text { if } \rightarrow y \neq 0}{\frac{1}{1+\exp (z)} \rightarrow \text { otherwise }}\right\}
$$

The binary panel model is fitted using maximum likelihood applying the Gauss-Hermite quadrature,

$$
l_{i} \approx \sqrt{2 \hat{\sigma}_{i}} \sum_{m=1}^{M} w_{m}^{*} \exp \left\{\left(a_{m}^{*}\right)^{2}\right\} g\left(y_{i t,} x_{i t,} \sqrt{\hat{\sigma}_{i}} a_{m}^{*}+\hat{\mu_{i}}\right)
$$


where, $\hat{\sigma}_{i}$ and $\hat{\mu}_{i}$ are the adaptive parameters for panel $_{i}$ and defined as $g\left(y_{i t}, x_{i t}, v_{i}\right)$ as the total log likelihood approximated by

$$
L \approx \sum_{i=1}^{n} w_{i} \log \left[\sqrt{2 \hat{\sigma}_{i}} \sum_{m=1}^{M} w_{m}^{*} \exp \left\{\left(a_{m}^{*}\right)^{2}\right\} \frac{\exp \left\{-\left(\sqrt{2 \hat{\sigma}_{i}} a_{m}^{*}+\hat{\mu}_{i}\right)^{2} / 2 \sigma_{v}^{2}\right.}{\sqrt{2 \pi \sigma_{v}}} \prod_{t=1}^{n_{i}} F\left(y_{i t,} x_{i t} \beta+\sqrt{2 \hat{\sigma_{i}}} a_{m}^{*}+\hat{\mu_{i}}\right]\right.
$$

where $w_{i}$ is the user-specified weight for panel $_{i}$ (Note 12). Furthermore, to derive a consistent variance-covariance estimator for our binary panel model when the disturbances are not identically distributed and panels are serial correlated with the error term $\left(\varepsilon_{i t}\right)$. To correct for heteroscedasticity and the effect of clustering among state pension plans over the time horizon analyzed, we apply the Huber-White-Sandwich variance-covariance robust/cluster estimator as stated in Wooldridge (2016), Stock \& Watson (2008), MacKinnon $\&$ White (1985), and Arellano (2003).

\section{Empirical Results}

This paper examines average annual returns based on average asset allocation of 160 SPPP from 2001 to 2015 . It should be noted that average returns for years, 1, 3, 5, 10 and 15 analysed in this paper exhibit serial correlation. SPPP data on single year returns by allocation and asset class is unavailable to the public for analysis and research. To address the issue of serial correlation and the unavailable data on single year returns, the authors ran five independent logit panel regressions (models 1-5, see table 4) on average returns (in years 1, 3, 5, 10 and 15) and by average allocation asset class. Our model defines the asset allocation portfolio as follows; the independent variables are US bonds, international bonds, US equities, international equities, alternatives, short-term cash, other and real estate (Note 13). The binary dependent variable $\operatorname{Pr}\left(\right.$ FundedRatio $\left._{i t}\right)$ is equal to one at or above the benchmark funded ratio of $80 \%$, otherwise equal to zero. The model introduces interaction terms (\#) for annual average returns and asset allocation as stated in equation [6] below. We apply a panel logit regression with random effects model to analyze the threshold of the funded ratio at a benchmark of eighty-percent. Our analysis examines asset allocation and investment choices measured by the likelihood of obtaining a funded ratio at or above the designated benchmark of $80 \%$. The model is defined as:

$$
\begin{aligned}
& \operatorname{Pr}\left(\text { FundedRatio }_{i t}\right)=\beta_{0}+\beta_{1} \text { Yr\#USBonds }_{i t}+\beta_{2} \text { Yr\# IntBonds }_{i t}+\beta_{3} Y_{r} \# U S \text { Equities }_{i t}+\beta_{4} Y_{r} \# \text { IntEquities }_{i t} \\
& +\beta_{5} \text { Yr\# Alternatives }{ }_{i t}+\beta_{6} Y r \# \text { Cash }_{i t}+\beta_{7} Y r \# \operatorname{Re} \text { alEstate }_{i t}+\beta_{8} Y r \# \text { Other }_{i t}+v_{i}+\varepsilon_{i t}
\end{aligned}
$$

The regression results (see Table 4 below) show average returns and the likelihood (probability) of obtaining a funded ratio at or above the benchmark of $80 \%$. The marginal effects indicate that for all assets classes, the funded ratio is less likely to be funded at or 


\section{Mll Macrothink}

International Journal of Accounting and Financial Reporting

ISSN 2162-3082

2019, Vol. 9, No. 1

above the benchmark for average returns in years $1(-36.4 \%), 3(-38.7 \%)$, and $15(-31.5 \%)$ and more likely in year $5(80.8 \%)$. For average returns and asset allocation, the funded ratio is more likely (Note 14) to be at or above its benchmark when investing in U.S. equities in years $3(10.7 \%), 5(36.4 \%)$ and $10(36.75 \%)$; short-term cash in years 1 (32.8\%), $5(55.8 \%)$, $10(79.4 \%)$; and real estate in year $5(71.1 \%)$, and year $10(77.8 \%)$. It is less likely to have a funded ratio at or above the benchmark at the average asset allocation in alternatives as outlined in Table 1. Our regression results show that for year 1, there is $29.9 \%$ less likelihood of the funded ratio at or above the benchmark. Similar results follow for years $3(-52.5 \%), 5$ $(-58.3 \%), 10(-72.1 \%)$ and $15(-65.2 \%)$.

The inter-class correlation rho $(\rho)$ explains the individual specific effects among the different States and public pension plans. The rho for years 1, 3, 5, 10 and 15 are $69.5 \%, 75.5 \%$, $78.1 \%, 91.3 \%$ and $79.9 \%$, respectively. It is evident that rho levels are approximately $70 \%$ or greater indicating that individual specific effects dominate the overall variation in investment behavior and allocation choice among States and pension plans. The model fit given by McFadden's R-Squared for years 1 (78.7\%), 3 (26.4\%), 5 (21.2\%), 10 (55.2\%) and 15 $(19.5 \%)$.

Table 4. Results of the panel logit random effects model of state public pension plans average returns

\begin{tabular}{|c|c|c|c|c|c|c|c|c|c|c|}
\hline \multicolumn{6}{|c|}{ Logit RE Estimation } & \multicolumn{5}{|c|}{ Marginal Effects of Logit RE Estimation } \\
\hline \multicolumn{6}{|c|}{ Coefficient } & \multicolumn{5}{|c|}{ Coefficient } \\
\hline & Model 1 & Model 2 & Model 3 & Model 4 & Model 5 & Model 1 & Model 2 & Model 3 & Model 4 & Model 5 \\
\hline Variable & $1 \mathrm{yr}$ & $3 \mathrm{yr}$ & $5 \mathrm{yr}$ & $10 \mathrm{yr}$ & $15 \mathrm{yr}$ & $1 \mathrm{yr}$ & $3 \mathrm{yr}$ & $5 \mathrm{yr}$ & $10 \mathrm{yr}$ & $15 \mathrm{yr}$ \\
\hline & & & & & & $\begin{array}{l}-0.364 * * * \\
(0.064)\end{array}$ & $\begin{array}{l}-0.387 * * * \\
(0.148)\end{array}$ & $\begin{array}{l}0.808 * * * \\
(0.216)\end{array}$ & $\begin{array}{l}0.577 \\
(0.471)\end{array}$ & $\begin{array}{l}-3.156^{* * * *} \\
(0.255)\end{array}$ \\
\hline U.S. Bonds & $\begin{array}{l}-4.149 \\
(4.401)\end{array}$ & $\begin{array}{l}3.556 \\
(8.026)\end{array}$ & $\begin{array}{c}16.091 \\
(11.709)\end{array}$ & $\begin{array}{c}7.219 \\
(21.336)\end{array}$ & $\begin{array}{c}-41.208^{* *} \\
(16.941)\end{array}$ & $\begin{array}{l}-0.032 \\
(0.034)\end{array}$ & $\begin{array}{l}0.023 \\
(0.053)\end{array}$ & $\begin{array}{c}0.955 \\
(0.069)\end{array}$ & $\begin{array}{l}0.029 \\
(0.087)\end{array}$ & $\begin{array}{l}-0.114 \\
(0.047)\end{array}$ \\
\hline Int. Bonds & $\begin{array}{c}18.226 \\
(23.839)\end{array}$ & $\begin{array}{c}60.998 \\
(41.229)\end{array}$ & $\begin{array}{r}87.785 \\
(59.530)\end{array}$ & $\begin{array}{l}163.769^{*} \\
(99.698)\end{array}$ & $\begin{array}{c}97.099 \\
(69.363)\end{array}$ & $\begin{array}{l}0.141 \\
(0.184)\end{array}$ & $\begin{array}{l}0.402 \\
(0.267)\end{array}$ & $\begin{array}{l}0.521 \\
(0.348)\end{array}$ & $\begin{array}{l}0.669^{*} \\
(0.409)\end{array}$ & $\begin{array}{l}0.269 \\
(0.192)\end{array}$ \\
\hline U.S. Equities & $\begin{array}{l}5.008 \\
(3.185)\end{array}$ & $\begin{array}{l}16.285^{* * *} \\
(6.627)\end{array}$ & $\begin{array}{l}61.378^{* * *} \\
(11.671)\end{array}$ & $\begin{array}{l}89.751^{* * *} \\
(18.503)\end{array}$ & $\begin{array}{l}-12.125 \\
(14.085)\end{array}$ & $\begin{array}{c}0.039 \\
(0.025)\end{array}$ & $\begin{array}{l}0.107^{* * *} \\
(0.043)\end{array}$ & $\begin{array}{l}0.364 * * * \\
(0.065)\end{array}$ & $\begin{array}{l}0.367 * * * \\
(0.086)\end{array}$ & $\begin{array}{l}-0.336 \\
(0.039)\end{array}$ \\
\hline Int. Equities & $\begin{array}{l}-13.872 * * \\
(6.281)\end{array}$ & $\begin{array}{l}-23.067 \\
(13.747)\end{array}$ & $\begin{array}{l}-77.717^{* * * *} \\
(20.754)\end{array}$ & $\begin{array}{l}-73.828^{*} \\
(41.032)\end{array}$ & $\begin{array}{r}-51.429^{*} \\
(31.461)\end{array}$ & $\begin{array}{l}-0.107^{* *} \\
(0.049)\end{array}$ & $\begin{array}{l}-0.152^{*} \\
(0.089)\end{array}$ & $\begin{array}{l}-0.461^{* * * *} \\
(0.119)\end{array}$ & $\begin{array}{l}-0.302^{*} \\
(0.174)\end{array}$ & $\begin{array}{l}-0.143 \\
(0.087)\end{array}$ \\
\hline Alternatives & $\begin{array}{l}-38.683^{* * *} \\
(5.406)\end{array}$ & $\begin{array}{l}-0.299 * * * \\
(0.044)\end{array}$ & $\begin{array}{l}-98.169 * * * \\
(18.262)\end{array}$ & $\begin{array}{l}-176.477^{* * *} \\
(44.026)\end{array}$ & $\begin{array}{l}-234.537^{* * *} \\
(32.390)\end{array}$ & $\begin{array}{l}-0.299 * * * \\
(0.044)\end{array}$ & $\begin{array}{l}-0.525^{* * *} \\
(0.074)\end{array}$ & $\begin{array}{l}-0.583^{* * *} \\
(0.103)\end{array}$ & $\begin{array}{l}-0.721^{* * * *} \\
(0.164)\end{array}$ & $\begin{array}{l}-0.652^{* * *} \\
(0.083)\end{array}$ \\
\hline Cash & $\begin{array}{l}42.485^{* * *} \\
(15.620\end{array}$ & $\begin{array}{l}0.328^{* * * *} \\
(0.122)\end{array}$ & $\begin{array}{l}93.990^{* *} \\
(40.994)\end{array}$ & $\begin{array}{l}194.344^{* * * *} \\
(68.192)\end{array}$ & $\begin{array}{r}-107.979 \\
(77.851)\end{array}$ & $\begin{array}{l}0.328 * * * \\
(0.122)\end{array}$ & $\begin{array}{l}0.313 \\
(0.228)\end{array}$ & $\begin{array}{c}0.558^{* *} \\
(0.246)\end{array}$ & $\begin{array}{l}0.794^{* * * *} \\
(0.300)\end{array}$ & $\begin{array}{l}-0.299 \\
(0.215)\end{array}$ \\
\hline Real Estate & $\begin{array}{c}9.399 \\
(14.549)\end{array}$ & $\begin{array}{l}0.073 \\
(0.113)\end{array}$ & $\begin{array}{l}119.716^{* * * *} \\
(41.607)\end{array}$ & $\begin{array}{l}190.534^{*} \\
(99.770)\end{array}$ & $\begin{array}{c}58.626 \\
(64.125)\end{array}$ & $\begin{array}{l}0.073 \\
(0.113)\end{array}$ & $\begin{array}{l}0.157 \\
(0.165)\end{array}$ & $\begin{array}{l}0.711^{* * * *} \\
(0.244)\end{array}$ & $\begin{array}{l}0.778^{*} \\
(0.403)\end{array}$ & $\begin{array}{l}0.163 \\
(0.180)\end{array}$ \\
\hline Other & $\begin{array}{c}-22.718 \\
(19.584)\end{array}$ & $\begin{array}{l}-0.175 \\
(0.151)\end{array}$ & $\begin{array}{c}11.730 \\
(43.490)\end{array}$ & $\begin{array}{l}-66.610 \\
(92.589)\end{array}$ & $\begin{array}{r}-138.825 \\
(87.080)\end{array}$ & $\begin{array}{l}-0.175 \\
(0.151)\end{array}$ & $\begin{array}{c}-0.384 \\
(0.317)\end{array}$ & $\begin{array}{l}0.069 \\
(0.258)\end{array}$ & $\begin{array}{l}-0.272 \\
(0.375)\end{array}$ & $\begin{array}{l}-0.386 \\
(0.244)\end{array}$ \\
\hline Constant & $\begin{array}{l}0.316 \\
(0.228) \\
\end{array}$ & $\begin{array}{c}0.198 \\
(0.277)\end{array}$ & $\begin{array}{l}-0.506^{*} \\
(0.296)\end{array}$ & $\begin{array}{l}-2.331^{* * *} \\
(0.877)\end{array}$ & $\begin{array}{l}1.511^{* * *} \\
(0.314)\end{array}$ & $\begin{array}{l}- \\
-\end{array}$ & $\begin{array}{l}- \\
-\end{array}$ & - & $\begin{array}{l}- \\
-\end{array}$ & - \\
\hline $\operatorname{sigma}(v)$ & 2.014 & 2.314 & 2.463 & 3.540 & 2.569 & $(0.187)$ & $(0.213)$ & $(0.198)$ & $(0.392)$ & $(0.202)$ \\
\hline $\operatorname{sigma}(\varepsilon)$ & 2.738 & 3.179 & 3.427 & 5.872 & 3.613 & $(0.256)$ & $(0.338)$ & $(0.339)$ & $(1.152)$ & $(0.366)$ \\
\hline rho & 0.695 & 0.755 & 0.781 & 0.913 & 0.799 & $(0.039)$ & $(0.039)$ & $(0.034)$ & $(0.031)$ & $(0.033)$ \\
\hline McFadden R2 & 0.787 & 0.264 & 0.212 & 0.554 & 0.195 & & & & & \\
\hline $\mathrm{N}$ & 2,320 & 1,929 & 2,184 & 1,498 & 2,363 & & & & & \\
\hline
\end{tabular}

Note: Estimated coefficients, robust standard errors and p-values from panel random effects logit regression and their respective marginal effects computed by average returns and asset allocation.

\section{Conclusion}

The issue of an adequately funded SPPP is of a concern not only to beneficiaries, but portfolio managers as well. The data show that after 2007, the allocation of alternative assets 
relative to the overall portfolio has increased from $6.3 \%$ in 2007 to $17.1 \%$ in 2015 . We show that increases in the allocation and subsequent investment in alternative assets by portfolio managers was a strategy primarily focused on making up for lost ground due to the Great Recession. In the short-term, greater allocation and investment in alternative assets was intended to alleviate losses subsequent to the financial crisis of 2008-2009 with the goal of long-term funded ratio to be at or above the threshold of eighty percent. Our findings demonstrate that diverting pension funds away from traditional assets such as bonds, equities and short-term cash into alternatives may not adequately address the issue of long-term sustainability and the underfunding of SPPP. Conversely, the strategy of directing greater levels of asset allocation into alternatives as a long-term solution during periods of low economic growth or recessions may not alleviate the underfunding of payment obligations. The data show that the average returns for alternatives in the long-term are mixed.

The results have policy implications for pension plan investment managers and their beneficiaries. In conclusion, in the long-term, making alternatives as part of pension plans portfolio may not result in commensurate average returns given inherent risks in non-traditional assets.

\section{References}

Aglietta, M., Briere, M., Rigot, S., \& Signori, O. (2012). Rehabilitating the Role of Active Management for Pension Funds. Journal of Banking and Finance, 36, 2565-2574.

Arellano, M. (2003). Panel Data Econometrics (Chapter 3). Oxford: Oxford University Press. Aubry, J., Chen, A., \& Munnell, A. (2017). A First Look at Alternative Investments and Public Pensions. Retrieved February 17, 2019, from https://crr.bc.edu/wp-content/uploads/2017/06/slp_55.pdf

Blake, D., Sarno, L., \& Zinna, G. (2017). The market for lemmings: The herding behavior of pension funds. Journal of Financial Markets, 26, 17-39.

Cameron, C. A., \& Miller, D. L. (2015). A practitioner's guide to cluster-robust inference. Journal of Human Resources, 50, 317-373.

Dobra, M., \& Lubich, B. (2013). Public Pension Governance and Asset Allocation. The Business and Economics Research Journal, 6(1), 83-101.

Elder, E., \& Wagner, G. (2016). Can Public Pensions Fulfill Their Promises? An examination of Pennsylvania's Two Largest Public Pensions. Municipal Finance Journal, 37(3), 1-22.

Gillers, H. (2017, August 9). Stock Rally Fails to Fill Pension Shortfalls. Wall Street Journal, B1.

Groot, W. D., \& Swinkels, L. (2008). Incorporating uncertainty about alternative assets in strategic pension fund asset allocation. Pensions: An International Journal, 13(1-2), 71-77. 


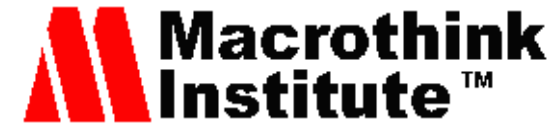

International Journal of Accounting and Financial Reporting ISSN 2162-3082 2019, Vol. 9, No. 1

Hoevenaars, R., Molenaar, R., Schotman, P., \& Steenkamp, T. (2008). Strategic Asset Allocation with Liabilities: Beyond Stocks and Bonds. Journal of Economic Dynamics \& Control, 32, 2939-2970.

Huber, P. J. (1967). The behavior of maximum likelihood estimates under nonstandard conditions. Proceedings of the Fifth Berkeley Symposium on Mathematical Statistics and Probability (Vol. 1, pp. 221-233). Berkeley: University of California Press.

Jackwerth, J. C., \& Slavutskaya, A. (2016). The total benefit of alternative assets to pension fund portfolios. Journal of Financial Markets, 61, 25-42.

Kanuri, S., \& McLeod, R. W. (2014). Performance of alternative mutual funds: The average investor's hedge fund. Financial Services Review, 23, 93-121.

Kraussel, R., Lehnert, T., \& Rinne, K. (2017). The search for yield: Implication to alternative investments. Journal of Empirical Finance. Retrieved from https://ssrn.com/abstract=3066673

Listokin, S., Pfaff, J., Samuda, K., \& Wedel, J. (2015). U.S. Public Pension Funds and Alternative Investments: Uneven Investment Policies, Uneven Results. Institute for New Economic Thinking Policy Paper. Retrieved February 18, 2018, from https://www.ineteconomics.org/research/research-papers/u-s-public-pension-funds-and-altern ative-investments

Lucas, D., \& Zeldes, S. (2009). Pensions and Health care: fiscal Challenges for State and Local Governments. American Economic Review: Papers and Proceedings, 99(2), 527-532.

MacKinnon, J. G., \& White, H. L. Jr. (1985). Some heteroskedasticity-consistent covariance matrix estimators with improved finite sample properties. Journal of Econometrics, 29, 305-325.

Mohan, N., \& Zhang, J. (2014). An Analysis of Risk-Taking Behaviour for Public Defined Benefit Pension Plans. Journal of Banking and Finance, 40, 403-419.

Pennacchi, G., \& Rastad, M. (2011). Portfolio allocation for public pension funds. Journal of Pension Economics \& Finance, 10(2), 221-245.

Public Plans Database. (2017). Center for Retirement Research at Boston College. Retrieved June 28, 2017, from http://crr.bc.edu/data/public-plans-database/

Stalebrink, O. (2014). Public Pension Funds and Assumed Rates of Return: An Empirical Examination of Public Sector Defined Benefit Pension Plans. American Review of Public Administration, 44(1), 92-111.

Stock, J. H., \& Watson, M. W. (2008). Heteroskedasticity-robust standard errors for fixed effects panel data regression. Econometrica, 76, 155-174.

Wang Q., \& Peng, J. (2016). An Empirical Analysis of State and Local Public Pension Plan Funded Ratio Change, 2001-2009. American Review of Public Administration, 46(1), 75-91. 


\section{MInstitute Macrothink $^{m}$}

International Journal of Accounting and Financial Reporting

ISSN 2162-3082

2019, Vol. 9, No. 1

Wooldridge, J. M. (2016). Introductory Econometrics: A Modern Approach (6th ed., Chapter 14). Boston: Cengage.

\section{Notes}

Note 1. The Pension Benefit Guaranty Corporation-PBGC-regulates private defined benefit plans and provides insurance plan in the event of termination of private pension plans $\begin{array}{llll}\text { (retrieved } & \text { March } & 13, & \text { 2018, from }\end{array}$ https://www.pbgc.gov/documents/Investment-Policy-Statement.pdf) recommends that investment in fixed income assets (bonds and money market) be at $70 \%$ while investment in non-fixed income assets be at $30 \%$ with a caveat that prudent risk taking is justifiable.

Note 2. The Public Pension Plan Data used is from the Center for Retirement Research at Boston College, August 3, 2017. The analysis is based on 160 SPPP found on public plans database from 2001 to 2015.

Note 3. "Other" is a very small group that includes miscellaneous categories, including groupings such as bank loans, inflation-linked assets and opportunistic investments.

Note 4. For our analysis we have sub-divided all equities and all bonds into U.S. and international equities and bonds, respectively.

Note 5. Beta measures volatility or systemic risk of a financial instrument in comparison to the market as whole. Beta of 1 means the security price moves with the market, beta of less than 1 means that the security is theoretically less volatile than the market. Beta of greater than 1 indicates that the security's price is theoretically more volatile than the market.

Note 6. http://publicplansdata.org/

Note 7. References the U.S. Census Bureau database as of 2016.

Note 8. http://publicplansdata.org/quick-facts/national/

Note 9. The total number of observations analyzed is $\mathrm{N}=2400$.

Note 10. Kaiser, Boris (2014), "RHAUSMAN: Stata module to perform a (cluster-) robust Hausman test", University of Bern.

Note 11. Hausman Test result is Prob $>$ chi2 $=0.7168$ indicating that the Random Effects model is appropriate.

Note 12. Stata v.15 longitudinal data and panel data reference manual.

Note 13. For definitions of independent variables see Appendix.

Note 14. Likelihood or probability of obtaining a funded ratio at or above the benchmark of $80 \%$ is given in parentheses for years $1,3,5,10$ and 15 for assets. 


\section{Appendix: Variable Definitions}

Yr Average annual returns based on average asset allocation in alternatives, short-term cash, US equities, International equities, US bonds, international bonds, other and real estate for fiscal years 1, 3, 5, 10 and 15.

Alternatives Percent of assets invested in alternatives (private equity, hedge funds, and commodities).

Cash Percent of assets invested in cash \& short term (financial investments of relatively short duration that generally present low risk and lower returns but are more liquid than other investments).

USEquities Percent of assets invested in US equities (fixed income- generally considered low-risk investments).

IntEquities Percent of assets invested in International Equities (fixed income-generally considered low-risk investments).

USBonds Percent of assets invested in US bonds (fixed income- generally considered low-risk investments).

IntBonds Percent of assets invested in foreign Bonds (fixed income- generally considered low-risk investments).

Other Percent of assets invested in other (bank loans, inflation-linked assets and opportunistic investments).

RealEstate Percent of assets invested in real estate (considered as an alternative asset).

\section{Copyright Disclaimer}

Copyright for this article is retained by the author(s), with first publication rights granted to the journal.

This is an open-access article distributed under the terms and conditions of the Creative Commons Attribution license (http://creativecommons.org/licenses/by/4.0/) 